\title{
The Relationship between the 21st Century Maritime Silk Road Initiative and Chinese Naval Strategy
}

(Research Article)

21. Yüzyıl Deniz İpek Yolu Girişiminin Çin Donanma Stratejisi ile İlişkisi

Doi: 10.29023/alanyaakademik.673794

Göktürk TÜYSÜZOĞLU

Doç. Dr., Giresun Üniversitesi, İ̈BF, Uluslararası İlişkiler Bölümü

gktrkt@gmail.com

Orcid No: 0000-0001-9170-1854

\section{Cenk ÖZGEN}

Dr. Öğr. Üyesi, Giresun Üniversitesi, İ̈BF, Siyaset Bilimi ve Kamu Yönetimi Bölümü

cenk_ozgen79@hotmail.com

Orcid No: 0000-0002-8583-6194

How to cite this article: Tüysüzoğlu, G. \& Özgen, C. (2020). The Relationship between the 21st Century Maritime Silk Road Initiative and Chinese Naval Strategy. Alanya Academic Review, 4(2), Sayfa No. 283-303.

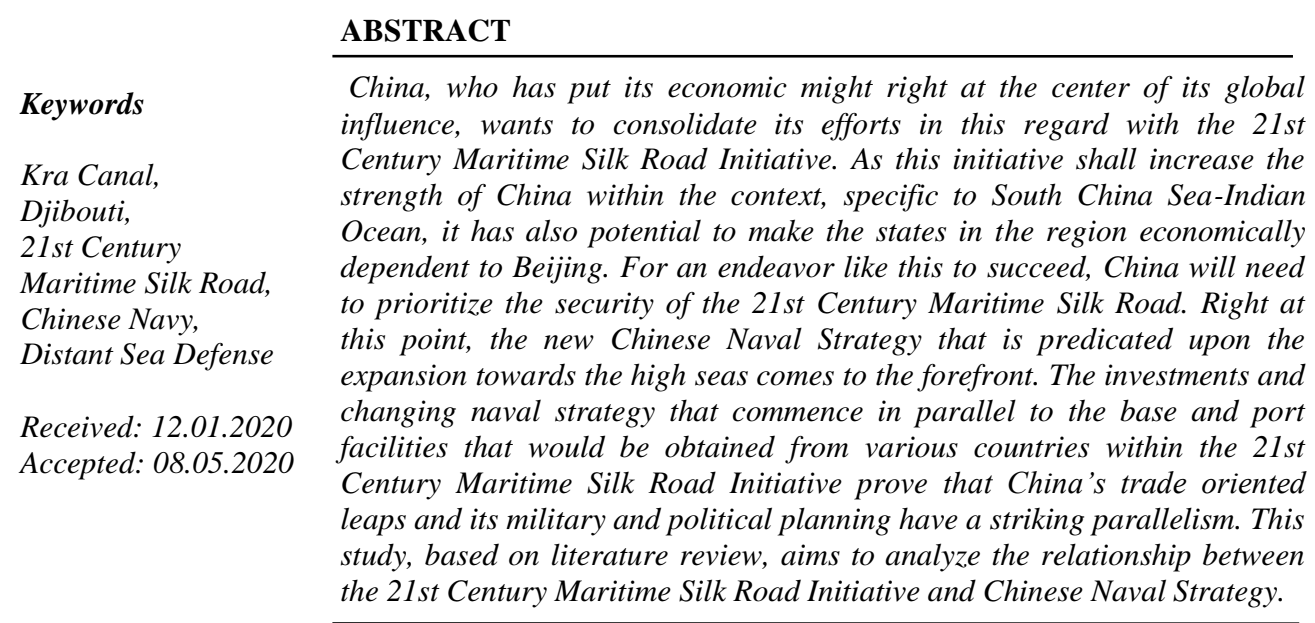

\section{INTRODUCTION}

As a result of reforms introduced in 1978 that opened China to the global economy and transitioned it to a new economic model of "state capitalism", China has seen rapid economic growth and development. In fact, in 2014, China succeeded in surpassing United States GDP by purchasing power parity (PPP) - thus, China's economy, when assessed in terms of PPP, has since knocked the US out of top spot for the world's largest economy. Moreover, despite its slowing growth rate in recent years, projections indicate that China will also likely surpass the US in terms of real, or nominal, GDP before the 2030s (PwC, 2015: 1). 
Fully integrated into the global economy, China exports the vast majority of its goods to foreign markets primarily via maritime transportation. However, maritime transport also plays a vital rolein meeting China's energy needs. Oil and gas tankers, primarily imported from the Middle East and Africa, have to sail through the sea lines of communications (SLOCs) and choke points under the control of the US Navy (Tata, 2017) to reach China. Tankers navigating in the West-East bearing reach China's eastern ports through SLOCs in the Indian Ocean - South China Sea axis, with choke points at the straits of Hormuz and Malacca. China imports at least $51 \%$ of its oil from the Middle East and about $43 \%$ of this amount goes through the Strait of Hormuz. The figures in relation to the Strait of Malacca are even more striking - $82 \%$ of the oil and $30 \%$ of the natural gas (in the form of LNG) that China imports goes through this narrow waterway (Bender and Rosen, 2015) - hence, Chinese President Hu Jintao's characterization of the dependency on this strait as the "Malacca Dilemma” (Storey, 2006).

Because China is well aware of the significance of maritime transportation for commercial use, it strives for the improvement of maritime infrastructure and towards ensuring security of the SLOCs. Announced in 2013, the $21^{\text {st }}$ Century Maritime Silk Road, one of several of China's maritime improvement initiatives, is perhaps amongst the most intriguing because of its potential economic and military outcomes. This initiative aims to improve maritime transportation infrastructure with a parallel goal to increase China's economic and political influence in its neighborhood. Importantly, the Maritime Silk Road is also meant to help China in obtaining overseas naval bases and ports, therefore continuing progress on increasing logistical capabilities of its navy.

This study, based on literature review, aims to analyze the relationship between the $21^{\text {st }}$ Century Maritime Silk Road Initiative and Chinese Naval Strategy. For this purpose, first, the Maritime Silk Road shall be discussed in a broad sense. Then, we will analyze China's relations with countries relevant to the Maritime Silk Road. Finally, we will look at the transformation of the Chinese Naval Strategy in relation to the Maritime Silk Road. There are parts of the Maritime Silk Road that stretch up to Western Pacific and Mediterranean but in order to avoid over-spreading the subject, this hereby study is limited with the effects of the initiative on the Indian Ocean-South China Sea axis.

\section{THE 21ST CENTURY MARITIME SILK ROAD}

Heavily affected by the 2008 global economic crisis, China initiated a large-scale economical/commercial hegemonic venture after Xi Jinping took the helm of the Communist Party (Cai, 2017). The One Belt, One Road Initiative appeals to a rather wide geographical area. It starts at China's borders and encompasses the Middle East, Europe and even Eastern Africa. The political impact of this initiative, which is expected to include 65 countries, will be significant in relation to its economic reverberations (Huang, 2017).

The initiative, considered a modern revival of the Silk Road, will be built on two main axes. The first is known as the Silk Road Economic Belt and is projected to include three different roads. This route is anticipated to start from Xinjiang, the westernmost province of China, and will extend towards Central Asia to Turkey and Europe over the Caspian-Caucasian connection. For this route to become operational, Russia's cooperation will be paramount - it will be important for China and Russia to understand the mutual benefits and develop trust in this partnership (Engelbrekt and Watts, 2015). Moscow, in fact, holds serious political influence within the Central Asia-Caucasian connection through which the route will pass. The second route is rather limited. It will start from China and shall extend to Mongolia and 
from there to Russia. This route is valuable in terms of deepening and strengthening the scope of cooperation between China and Russia. The third part, where construction crews are already busy at work, is known as the China-Pakistan Economic Corridor. China is putting considerable investments in Pakistan for the construction of this corridor (Hussain, 2017). The total cost, which was initially estimated as 46 billon USD, has now surpassed 62 billon USD (Siddiqui, 2017). China's serious investment in renewing Pakistan's infrastructure includes a) highways, to ensure commercial flow, b) railways, to allow for transport via fast train routes, c) airports d) oil pipelines and, e) a large port/oil refinery complex in Gwadar, which is situated on the shore of the Omani Sea. This port, and Pakistan in general, will be the most important hub of the connection that China plans to establish with Eastern Africa and the Middle East due to the high volume of commercial workload it is expected to carry (Khan, 2013: 87-100).

The second axis, or element, of the One Belt, One Road Initiative is dubbed as the $21^{\text {st }}$ Century Maritime Silk Road. The construction of this road is an attempt to increase China's export to its target regions and to ensure the security of the SLOCs. The road will connect China to the Persian Gulf (over the Indian Ocean), to Eastern Africa, and finally to the Mediterranean over the Red Sea. Advanced port facilities along the indicated route and channels designed to save on time (and therefore, money) will help to facilitate smoother commercial flows. The southern provinces on the shores of the Malacca Strait, known as centers of production and export in China, are intended to be integrated into Beijing's belt of influence as the result of the infrastructure investments and the support of loans/grants. Furthermore, different transportation projects that will provide further diversity to China's trade and energy strategy by bypassing the Malacca Strait are also on the table (Blanchard and Flint, 2017: 223-245). In fact, Beijing has made it clear that China's dependence on the Malacca Strait is no longer strategically acceptable nor sustainable. China also foster close contact with various countries located in regions relevant to the project in the Indian Ocean and in Eastern Africa. For China, the most important goal related to the $21^{\text {st }}$ Century Maritime Silk Road is to reach the Middle East and Eastern Africa through a safe route and to ensure a connection to Europe through the Greek port of Piraeus.

\section{SIGNIFICANT COUNTRIES IN TERMS OF THE INITIATIVE}

\subsection{Thailand}

Thailand is in a highly strategic position in relation to the Malacca Strait. After the Shinawatra Administration was toppled by the army, Thailand is now under a military administration. China, an avid economic and commercial partner for Thailand's current military administration, places particular importance on this country (Parameswaran, 2018).

With these considerations in mind, China has continued to bolster the "Kra Channel Project" a route that will pass through Thailand and will connect the Indian Ocean to the China Sea and the Pacific. To be constructed on the southern side of Thailand, this channel will allow ships that come from the Indian Ocean to reach the South China Sea directly without ever entering into the Malacca Strait. On average, this would save a distance of $1.200 \mathrm{~km}$ and 2-3 days of travel time. China continues to eagerly foster its relationship with Thailand in the hopes of obtaining clearance to build this route at an anticipated cost of 28 billion USD (Murdoch, 2017). China has continuously expressed its economic, technological and political power to assure the Thai government of its ability to build this channel. Furthermore, various Western companies that have investments in Thailand and that have close commercial ties there also support the construction of this channel. Given that the construction of this channel 
will likely elevate China-Thailand relations, it has the power to make Thailand one of the most important commercial hubs of the Asia-Pacific Region.

\subsection{Singapore}

Singapore, a port town in the Malacca Strait, is critical for every country that is dependent on the Strait. Singapore has a rather significant ethnic Chinese population and has maintained close economic, commercial and diplomatic ties with Beijing since the establishment of diplomatic relations with China in 1990. It also helps China to justify its position in ASEAN in relation to other membership and is one of the most important partners for China in the region. Singapore, however, fosters close military and diplomatic ties with the US. Hence, it has sought to strike a delicate balance in terms of its foreign relations to these two countries (Tarabay, 2017). Despite its strong ties to China, Singapore opposes Beijing's claims regarding the South China Sea. This has alerted the city-state to potential tensions in ASEAN, and has made Singapore weary of a possible escalation in a potential conflict of interest on the issue between the US and China. Such an escalation could turn a regional crisis into one that is large in scale.

A further complication is Singapore's military relationship with Taiwan, which has placed a strain on Singapore-China relations. An incident in 2016 only exacerbated this strain. The incident was related to China's seizure of a number of armored vehicles belonging to the Singaporean Army on their way to Singapore from Taiwan after a military drill. The vehicles were seized at customs in Hong Kong on the grounds that the US Company, which was responsible for the transportation of those vehicles, did not have the necessary documentation. After detaining the military assets for some time, China released them back to Singapore (Zhen, 2017). Despite the fact that the tension only lasted for a few months, China did not invite Singapore to the One Belt, One Road Summit in 2017. This decision was made as a response to Singapore's ever closer relations to the US and due to China's discomfort with Singapore's stance in relation to the South China Sea. However, these tensions have not had a significant bearing on trade relations between the two countries. Singapore remains the $9^{\text {th }}$ largest commercial partner for China, while China is Singapore's $3^{\text {rd }}$ largest trade partner. Furthermore, Singaporean capital investment will support the construction of major projects such as the Suzhou Industrial Park, Tianjin Eco-City and Guangzhou Science City in China (Ping, 2017). China needs Singapore because of its dependency on the Malacca Strait. Nonetheless, the Kra Channel Project, an item consistently on China's agenda for Singapore, will remain a critical element that might very well determine the state of future relations between Singapore and China. With the $21^{\text {st }}$ Century Maritime Silk Road, one of China's main imperatives will be to end its dependency on the Malacca Strait, and therefore its heavy dependency on Singapore.

\subsection{Malaysia}

In the context of ASEAN, Malaysia is one of China's most important trade partners. It is China's third biggest trade partner in Asia, only behind Japan and South Korea (China Daily, 2014). Malaysia, as one of the main players in the so-called Bamboo Network that China established with countries with which it has kinship or cultural ties in Asia-Pacific (Quinlan, 2007), also hosts a considerably large population with Chinese origin that has a prominent role in Malaysian business scene. China has the largest investments in Malaysia. Many infrastructure projects in the country, especially the transportation network, are constructed by Chinese companies or by means of Chinese capital. Though Malaysia and China do have some disputes regarding the South China Sea issue, these have not tended to escalate. The 
Malaysian government reasons that China will continue its commerce and investment oriented cooperation with states in the region, unless specifically provoked regarding the South China Sea issue - and thus, Malaysia steers clear of locking heads directly on this issue. It also deduces that utilizing the economic and commercial potential of China is a much more important imperative to Malaysia than entangling itself in these disputes. Mahathir Muhammed, Malaysia's current Prime Minister, has expressed that the US and its allies have tried to influence countries around the South China Sea to lean towards the US in relation to the US-China rivalry, and has thus overemphasized the idea of Beijing as a regional threat. An incident in 2015 illustrates Malaysia's position on this issue - when a ship from the Chinese Navy (and after, some Chinese fishing boats) cruised around the Lucconia Sands in the South China Sea, considered to be under Malaysian jurisdiction, Malaysia did, in fact, react against this situation (Han, 2016). However, this reaction did not lead to any larger scale tensions or have any major impact on the bilateral relations between the two countries. Commerce and investment oriented strategic initiatives continued to be prioritized. Malaysia will certainly have a significant role in the $21^{\text {st }}$ Century Maritime Silk Road due to its special location in relation to the Malacca Strait.

\subsection{Indonesia}

Indonesia is one of the most critical elements in the Bamboo Network - not only does it hold a strategic position in regard to the Malacca Strait, but also have a large population (thus, large market opportunity) and a convenient location on critical shipping points. Indonesia is China's most important trade partner within the ASEAN network after Malaysia, Singapore and Thailand. As of 2016, trade volume between the two countries has reached approximately 49 billion USD, with China's share about twice that of Indonesia's (OEC, 2016a). After Singapore, China is Indonesia's second biggest supporter, especially in terms of infrastructure investments. The Jakarta-Bandung High Speed Train Line, which is one of the most important transportation projects in the country, is being constructed by China (Kratz and Pavlicevic, 2016). This line is holds particular importance to China in relation to the $21^{\text {st }}$ Century Maritime Silk Road.

For many years, Indonesia did not cause rifts with China on disputes related to the South China Sea. However, more recently, relations between the two countries have become strained on this issue. These tensions are due to the fact that China's declared "Nine-Dash Line" intersects with Jakarta's exclusive economic zone (EEZ) around the Natuna Islands. While Beijing acknowledges that the Natuna Islands are Jakartan soil, it also indicates that China has traditional fishing rights in the vicinity of this island chain and thus sends fishing boats and the coast guard crafts that are tasked to protect the indicated boats to the region. Indonesia on the other hand, rejects this situation, which is in violation with the UNCLOS dated 1982. In 2016, the Indonesian coast guard attempted to stop Chinese fishing boats that entered its EEZ - they were soon met with Chinese coast guard boats and a short-lived crisis unfolded between the two countries. Although this case cooled down before it escalated, the Indonesian President, Joko Widodo, visited Natuna Islands in June 2016 onboard an Indonesian warship thus sending a clear message to Beijing that the country shall defend its rights around this island chain (Connelly, 2017). Afterwards, Indonesia renamed the disputed waterway as the "Northern Natuna Sea", thus once again underlining that Jakarta wants China to respect the rights of Indonesia in this region. China did not push on the subject after this incident. 


\subsection{Philippines}

Sino-Philippine relations have taken on a warmer character after Rodrigo Duterte took the helm of the nation. Despite the fact that the Philippines is a member of ASEAN and is a part of the Bamboo Network, we see that the trade between those two countries has remained stagnant due to ongoing political tensions. Figures on trade volume between those two countries hold at 42 billion USD (OEC, 2016b). The main reason that commercial and economic relations between the Philippines and China has taken a backseat despite the fact that such high trade volumes have been attained is the existence of the US military base in Manila. China understands that the Philippines play a significant role in Washington's regional strategy to counter Beijing (Greitens, 2016). The South China Sea issue has also caused a critical rift. China's claims on various islands, islets and sand dunes, including the Spratly Islands and Scarborough Shoal, and its move to take control of the indicated areas by leveraging its navy, are the violations of the Philippines' EEZ (Zhang, 2017: 435-466). The Philippines could be slated to lose up to $80 \%$ of its EEZ in the South China Sea if China is allowed to carry on such moves. However, after the Philippines applied the International Permanent Court of Arbitration in The Hague, China's "Nine-Dash Line" was deemed illegal. Despite this fact, China has begun installing weapons systems on the Spratly Islands, the Scarborough Shoal and various other sand dunes, which it is beginning to transform into artificial islands. This clearly indicates that Beijing plans this region as a forward military outpost. China's expansionist ambitions worry other countries in the region and pushes them closer to actors that try to balance China's influence in the region, namely the US, Japan and India. However, Duterte, the current head of state for the Philippines, has prioritized relations with China and has stated that he shall form closer economic and commercial bonds with this country. Duterte's harsh criticism against Washington also caused the Philippines to pull away from the US and this has pleased the Beijing Administration (Heydarian, 2017: 220236). Despite these developments and Beijing's promises of financial aid to the Philippines, it will not be very easy for China to manipulate Manila, as it has been a traditional US ally.

\subsection{Vietnam}

It is apparent that Vietnam holds critical importance for China (Zhang, 2015). Vietnam has been locked in struggle with China throughout its history (the two countries even waged war from 1979 to 1990 due to "border conflicts"). Hanoi has had problems with Beijing for a long time over the ownership of the Spratly and Paracel Islands. Vietnam indicates that both islands are within its own EEZ and thus rejects Beijing's claims regarding the aforementioned islands (Perlez, 2012). In fact, some islands in both of these island chains are under Vietnamese control. However, as China does hold the majority of the islands and has even set up bases on some of them, Beijing has allowed the fishing boats to enter the areas under Vietnamese control. Moreover, in an effort to prevent Vietnamese boats from doing the same, Beijing has constantly harassed Vietnamese fishing boats and has even sunk some on occasion.

Vietnam has also made contacts with energy companies that seek to operate oil and gas fields around the Spratly and Paracel Islands, but conducting any actual work has been hindered by threats and coercion from China. China's prevention of drilling work in 2017 by Spanish REPSOL, despite the company having obtained Vietnam's permission, is a prime example of this (Reuters, 2018).

Because Vietnam perceives China as a threat, it has approached closer to Washington in hopes of balancing out China's regional influence. Hanoi made a strategic choice (Tuan and 
Thuy, 2016: 179-192). This choice fits in with the move to keep China in check in the AsiaPacific, initiated in the Obama era through the Pivot to Asia Policy and carried through to the Trump presidency. By cooperating with Vietnam, which is not a traditional US ally due to its adherence to state run communism, Washington has sent a signal that regional interests are more important than a country's system of governance.

\subsection{Myanmar}

In regard to Myanmar, China has established close ties with the "army", which holds influence over Myanmar's administration and is, in fact, currently a coalition partner. The military equipment that China provides to the Army of Myanmar is of critical importance.

China is the largest contributor to infrastructure investment in Myanmar. One such investment, for example, is the modernization and expansion of the Port of Sittwe. However, China's ambitions do not stop there - it is also keenly interested in the extraction of Myanmar's oil and gas reserves in the Bay of Bengal, and perhaps more importantly, on the shores of the Rakhine (Arakan) region. In fact, China has initiated a $2.389 \mathrm{~km}$ oil and natural gas pipeline to connect the Arakan region to the Chinese province of Yunnan (TNI, 2016). In addition to the development of the energy fields off the shores of Arakan, China shall construct a large-scale refinery in the region where the pipeline is being built. The natural gas pipeline, held by PetroChina, is anticipated to carry 2,88-3,56 trillion cubic meters of gas from the A-1 Shwe reserve site near Arakan to the Yunnan Province (Kolas, 2007: 625-643). One of the most important reasons for why the humanitarian crisis in Arakan was brought to global attention by Western media is, in fact, China's attempt to leverage this region as one of its most important regional bases. By means of the "Deep Sea Port" project initiated in Kyaukpyu, China aims to leverage Myanmar for the transport of energy resources from the Middle East and Northern Africa, allowing Beijing to bypass the Malacca Strait. This helps bolster China's strategic decisions to reduce its dependency on both the Strait and the countries in its vicinity.

Beijing also plans to convert the Sittwe and Kyaukpyu into naval bases (Perlez, 2017), therefore, expanding its military influence in the Bay of Bengal and allowing it to monitor India more closely. In fact, allegations attest to a naval forward monitoring and ELINT facility on Myanmar's Coco Island, but these allegations have been rejected by New Delhi (Lintner, 2017). One of China's largest infrastructure investments in Myanmar is the highway that was constructed between Yangon and Sittwe, two of Myanmar's most important cities. Amongst China's most important ambitions is to strengthen the land connection between Yunnan Province and the City of Rakhine, the westernmost part of Myanmar. The idea behind this endeavor, considered as a part of the Bangladesh-China-India-Myanmar Corridor Initiative (BCIM), is to allow a conduit for Beijing to spread its own trade influence and production standardization, a vision that will need the cooperation of India (Panda, 2016). However, regional rivalries and political problems with India has rendered this endeavor largely ineffectual.

\subsection{Sri Lanka}

Sri Lanka, an island situated in the Indian Ocean just south of India, is important to the Maritime Silk Road Initiative as a component of China's "String of Pearls" Strategy. Despite having little connection to the issue, Sri Lanka has sided with China on disputes related to the South China Sea. China plays an integral role in supporting Sri Lanka's military needs as a balance to the perception of threat from India. Beijing has dispatched nuclear-powered 
ballistic missile submarines (SSBNs) and nuclear-powered attack submarines (SSNs) to Sri Lanka, a move that New Delhi has perceived as a show of force against India (Singh, 2017a).

The Port of Hambantota and Hambantota International Airport, both built by China, are amongst the most important indicators of the importance that Beijing places on Sri Lanka. In exchange for the inability and eventual failure to pay back loans on these projects, the Sri Lankan Government has transferred the majority of its shares for the Port of Hambantota as partial payment on its debt. Colombo has a foreign debt stock of around 64 billion USD and an important portion of this debt is owed to Beijing. Some claim that China is seeking to manipulate Sri Lanka by driving it into a debt spiral. Beijing, for its part, sees the Port of Hambantota as a strategically acceptable home for its naval base in the Indian Ocean (Schultz, 2017). Analyses also suggest that the Hambantota Airport will also soon be subsumed under Chinese control, and that it too will be used for China's military activities in the region. Beijing has rejected such claims and has indicated that it intends to use Hambantota only for commercial purposes as an important station for the Maritime Silk Road.

Nevertheless, the case of Sri Lanka has made one thing perfectly clear - China's strategy to indebt certain countries is done so with the mind to make these countries dependent on China. While the Chinese administration may deny these allegations, it remains true that Colombo's role in the String of Pearls Strategy and the Maritime Silk Road will certainly be crucial.

\subsection{Pakistan}

The China-Pakistan Economic Corridor, which begins at Xinjiang in the west of China and reaches the Port of Gwadar in the Balochistan Province in southwest Pakistan, marks a Chinese investment of 62 billion USD. Within the project's scope is the construction of a large-scale highway from Urumqi to Gwadar over Pakistan through Kashgar, a high-speed railway connection, and oil/natural gas pipelines. The deep-sea port at Gwadar will be where the project connects to the Maritime Silk Road - this will serve as a junction port that could enable a part of the oil and natural gas that China imports from the Middle East and Northern Africa to be transported into China through refineries and pipelines serving to bypass the Malacca Strait. At the same time, China plans to use this port as an alternative route for its exports to Afghanistan and Central Asia (Chaturvedy, 2017).

India, China's biggest rival in the Indian Ocean, is not happy about Beijing trying to deepen its regional influence through a relationship with Islamabad, which has historically been at odds with New Delhi. Furthermore, despite China's claims that the Port of Gwadar will only be used for commercial (and energy trans-shipment) purposes, India is anxious about China converting the port into a naval base in the future. The move to Gwadar presents another interesting challenge for India. As India is unable to reach Afghan and Central Asian markets through Pakistan due to ongoing disputes with Islamabad, China's influence in Pakistan, and especially its easy access to the Port of Gwadar, seems like an endeavor to restrict India's own regional influence. Furthermore, India, who has made a large-scale investment to the Port of Chabahar, shall try to use this port as China intends to use. China also plans to use the refinery to be built in Gwadar for an energy-related cooperation with Iran (Tai, 2017: 1-12).

The partnership of India with China creates pressure on Washington that Islamabad shall be sided with Beijing. In an effort to counter-balance China, the US puts in significant effort to improve its relations with India, with the trade-off often being increased US pressures on Pakistan. 


\subsection{India}

Over the past few decades, India has formed close economic ties with ASEAN states through its "Look East" policy. However, since Narenda Modi took office, India has placed particular focus on strengthening its economic relations with ASEAN states via its "Act East" initiative (Palit, 2016: 81-91).While the Look East policy has succeeded, to a certain extent, in aiding India to form a closer relationship with ASEAN member states, China's increasing regional influence has become a cause for worry. As China continues to render countries in the region dependent on Beijing, and to institutionalize its regional influence through its One Belt, One Read initiative, sounds of alarm have gone off for New Delhi. China's further attempts to create a corridor with Pakistan, its trade and security oriented initiatives over Myanmar, and its progressively increased use of the Port of Hambantota in Sri Lanka (therefore, signaling more expansive Chinese activity in the South China Sea), have all forced India's hand to reevaluate its policies and to start making new moves.

Against this backdrop, New Delhi has made investments at the port of Chabahar in Iran to counteract China's initiatives in Pakistan. The aim is to use this port as a commercial base of operation. India also intends to develop highways, railroads and pipelines on a South-North axis to form its connection with Afghanistan and Central Asia (Roy, 2017). Azerbaijan and Russia will also be accessible through this route, providing easier access to Iranian oil and gas to all countries involved. The route could help to establish a commercial and energy-based strategic connection between New Delhi and Moscow. If China were to transform Gwadar into a naval base in the forthcoming period, India could well use Chabahar on the coast of the Arabian Sea for the same purpose. This would be an attempt to create a delicate balance between China and India on the mouth of the Indian Ocean.

India also aims to establish a link with ASEAN over its own northeastern territory within the scope of its Act East Strategy, as evidenced by projects such as the India-Myanmar Highway and the Kaladan Multi-Modal Transit Transport Network (Gadkari, 2018). However, several analyses have also pointed out that India needs to prioritize a maritime route in addition to its terrestrial projects. For India, the isles of Andaman and Nicobar, which are close to Myanmar, Thailand and Indonesia, can be used to establish easier connections to ASEAN nations. Those islands, too, can be utilized as potential naval bases close to the South China Sea (Raman, 2016). Such a move would be crucial to balance Chinese actions on the ports of Myanmar that open out to the Bay of Bengal.

India opposes China's actions in the South China Sea and states that Beijing's military activities in the area are a violation of international law. Furthermore, it is in New Delhi's interest to protect commercial activities dependent on the South China Sea from falling under Chinese control. As India supports the nations in the region that oppose the Chinese claims to the South China Sea, New Delhi has closely cooperated with the United States against everincreasing Chinese influence in the Indian Ocean. Joint military exercises, organized by India and the United States, with participation of Japan and Australia, prove that New Delhi is not alone in its attempt to balance Beijing's ambitions for regional power.

\subsection{Djibouti}

With its position that overlooks the Gulf of Aden, Djibouti is situated on the Red Sea-Indian Ocean connection. When the fact that $10 \%$ of the total world oil export and $20 \%$ of total world trade occurs on the Red Sea-Indian Ocean route is taken into account, the importance of the location of this country, whose population does not even exceed a mere million, can be understood much more clearly. The failure of Somalia to establish stability and to prevent the 
piracy in the section of the Indian Ocean that connects to Red Sea derive from the commercial potential and strategic importance of this region. Beijing, too, wishes to have an influential role in the region with plans to connect the $21^{\text {st }}$ Century Maritime Silk Road Initiative from the Port of Piraeus over Eastern Africa, the Middle East and the Mediterranean. Within this context, China has operated a naval base in Djibouti since July 2017 to combat piracy and to secure a long-term strategic position for its military facilities in the region. The Djibouti base, staffed by some 300 military service personnel, is the first overseas military base that China will operate. Beijing underlines that this base shall be used by its navy for peacekeeping missions, humanitarian security operations and for occasions that require rapid evacuation, adding that the base will also function to meet the logistical needs of Chinese ships (Reuters, 2017).

Djibouti also hosts the Camp Lemonnier naval expeditionary base, accounting for the largest US military presence in Africa. With this in mind, China's aforementioned activities are rather modest in comparison (Sun and Zoubir, 2016: 111-124). Furthermore, Djibouti also hosts some small-scale bases, used by France, Italy and even by Japan. Saudi Arabia, who has been battling with pro-Iranian Houthis in Yemen, also wishes to increase its influence in the region by commissioning a military base in Djibouti (Sputniknews, 2017).

\subsection{Kenya}

Kenya, which sits on the coast of the Indian Ocean in Eastern Africa, is known to be an important regional player. Kenya is considered as the most secure point in this region with coastal access to the Indian Ocean due to security risks in Somalia. As one of the most reliable regional partners for the United States, Nairobi has secured considerable political clout.

China wants to reach Eastern Africa by using this country as a commercial nexus or as a hub. The first stage of a railroad project that starts from Mombasa on the shore of the Indian Ocean to the capital city of Nairobi has been completed. The second stage of this 3,8 billion USD project is in the implementation phase (Xinhua, 2017). The second stage of this project was completed by a Chinese contractor with a Chinese loan. It connects South Sudan, Uganda, Rwanda and Burundi to the Port of Mombasa, therefore allowing Chinese goods to reach the region more easily. Beijing is also constructing an electricity plant anticipated to run on coal. The 2 billion USD price tag will be financed with Chinese loans and will be constructed by a Chinese contractor, much like the aforementioned railway construction project (Wesangula, 2018). Beijing, which has significantly indebted Kenya for infrastructural projects and loans, has also exercised its presence and power in some 30 more African nations through a diversity of investments, namely media. This is an exercise in soft power. Once the full potential of Chinese investments is realized in Kenya; this country would become one of China's most important partners in Africa.

\subsection{Sudan and South Sudan}

Khartoum, the closest ally to Beijing on the Red Sea route, also happens to be one of the key components of the Maritime Silk Road Initiative. While China is Sudan's most important export market, it also remains the country's largest partner for import. Beijing offers lowinterest loans to Khartoum. It also buys oil from this country and coordinates Sudan's oil related infrastructure through the China National Oil Company. World Bank data from 2016 shows Sudan's total debt at 50 billion USD - most of this debt is owed to China. The two countries have penned an agreement for a 10 billion USD payment on debt within the next five years (Amin, 2017). Thanks to Chinese support, certain steps towards the modernization 
of military assets such as tanks and aircrafts, navy and port investments and even the production of military equipment are being taken. Beijing is making significant investments to railway infrastructure in Sudan, such as the railroad construction project that connects the problematic Darfour region to other provinces of Sudan. China places importance on railroads and ports because Beijing plans to use these key infrastructure components for commercial transportation. China has made preliminary inroads on commercial activity in the area, and will continue to gradually increase these activities. Hence, these commercial aims will integrate with the strategic goals of the Maritime Silk Road.

The significance of improved transportation infrastructure is apparent when one takes a closer look at China's recent use of Sudan's most fertile lands, known as the Al Jazira region, for agricultural purposes, especially cotton production. Beijing also provides engineering and financial support to Sudan, in particular, for hydroelectric plants and dams in the Blue Nile Province (Amin, 2017).

South Sudan also holds a certain level of importance for China. Having experienced a catastrophic civil war as a result of its move for independence in 2011, South Sudan has lost almost the entirety of its already weak economic infrastructure. China, however, views Sudan holistically and wishes to integrate South Sudan's rich oil reserves with the Maritime Silk Road. In fact, Beijing holds $40 \%$ of shares of two different consortiums that produce oil in South Sudan. China has also provided a substantial amount of food aid to South Sudan while in the height of civil war and has committed serious military support to the UN peacekeeping force in the region. The peacekeeping mission in South Sudan was the first mission where China directly participated by committing its troops to the cause (Kuo, 2017).

\section{THE TRANSFORMATION OF CHINA'S NAVAL STRATEGY}

From its conception until the mid 1980's, China's People's Liberation Army Navy (PLAN) has pursueda Coastal Defense Strategy. This strategy was predicated upon defending the coasts of the homeland against the Soviet Pacific Fleet, which was perceived as the principal source of threat, and providing support to ground operations (Office of Naval Intelligence, 2009: 5). However, after the Admiral Liu Huaqing, considered as the father of the modern Chinese Navy and likened to the Mahan of China (Hartnett, 2014), became the naval force commander, PLAN strategists began working on a new strategic approach, known as Offshore Defense. Unlike the navies of the United States or Russia, which stand out due to their force projection capabilities, China's new naval strategy aimed for a force structure that would contribute to the protection of China's regional interests (Office of Naval Intelligence, 2009: 5). Relevant to our discussion here, China's new naval strategy makes reference to the protection of national assets and interests beyond its coastal waters. Hence, PLAN has set its sights on the high seas.

The term Offshore Defense was first used as a concept by Huaqing in 1987 (Office of Naval Intelligence, 2015: 5). Here, it is important to delineate several geographical concepts as related to Chinese military literature. Chinese strategists predicate the naval defense of their motherland upon a geographic arena conceptualized as the "Two Islands" chain. According to this concept, the First Island Chain stretches from north to south and encompasses the islands of Aleutand Kuril, Japan, the islands of Ryukyu, Taiwan, the Philippines and Borneo (Global Security, w.date). This chain extends a distance of 700 miles from the shores of China (Bennett, 2010: 128-129) and includes the Yellow Sea, the China Sea and the South China Sea. The Second Island Chain stretches from north to south and encompasses the Bonin, Marianna and Caroline islands, as well as Guam (Global Security, w.date). The second chain 
reaches a distance of 1.800 nautical miles from Chinese shores (Bennett, 2010: 129) andincludes the Japanese Sea, the Philippines Sea and the Indonesian Sea (Global Security, w.date).

This vast geographical expanse gives rise to a rather forceful list of aims within the scope of the Offshore Defense Strategy, i.e. deterring aggressors, defending the motherland, preventing the independence of Taiwan, supporting and contributing to nuclear deterrence efforts, ensuring the security of the SLOCs, defending sovereign rights within the maritime jurisdiction and authority and looking after overseas interests. During peacetime, the Offshore Defense Strategy stipulates to ensure absolute control within the First Island Chain and to have a permanent presence within the second one. During wartime, however, the very same strategy implies that enemy elements should be kept as far from the motherland as possible and should be terminated if and when necessary (Murray et al. 2015: 109-110). In Western literature, the Offshore Defense Strategy is regarded as a typical example of the Anti-Access and Area Denial (A2/AD) Strategy (McDevittand Jr., 2012: 76). This strategy is implemented to inhibit the access of hostile elements to a certain area/region and to prevent any hostile operations in the aforementioned geography. The Offshore Defense Strategy can be seen as a Chinese adaptation of $\mathrm{A} 2 / \mathrm{AD}$, which, for China, is understood to be the body of tactics, methods and procedures that collectively aim to keep aggressors away from the Second Island Chain. Hence, key components would include anti-ship ballistic missiles (ASBMs), anti-ship cruise missiles (ASCMs), attack submarines, guided missile cruisers, ground based aircrafts, air defense systems, sea mines and the command, control, communications, computers, intelligence, surveillance and reconnaissance (C4ISR) capabilities that support the indicated components.

The dissolution of the USSR has led China to perceive its northern neighbors as less threatening. On the other hand, China's perception of the threat level posed to it by the United States has elevated, especially after witnessing the effectiveness of the long-range assaults that the US performed in the first Gulf War, and particularly, after it deployed two Carrier Strike Groups to China's doorstep as the result of the tensions in Taiwan Strait between 19951996 (Murray et al. 2015: 108). Political, military and geostrategic interests combined with rapid economic development as a result of flourishing sea trade over the last two decades have heightened China's sensitivities to maritime matters.

Given these circumstances, PLAN follows a course in line with the two opposite but correlated phenomena - war and peace. Without a doubt, PLAN's principal task during wartime is the defense of the nation. Any hot conflict that may occur with Taiwan can be considered within this scope. What is really an innovation for PLAN are the tasks to be performed during the peacetime (McDevittand Jr., 2012: 75-76). The varieties of the indicated tasks are described in a white paper published by the State Council of the People's Republic of China titled "Military Operations Other Than War (MOOTW)". International peacekeeping operations, counter-terrorism and consolidation operations, patrol, search, rescue, humanitarian ops, as well as natural disaster relief and support missions are listed within the scope of the MOOTW (The State Council, 2015).

The approach of the Chinese leadership to international waters began shifting in the mid2000 's. One of the most solid indicators of this shift was a 2004 speech given by the Chinese Head of State, Hu Jintao, titled "The New Historic Missions". In his speech, Jintao identified the tasks and goals of the People's Liberation Army (PLA). Critically, Jintao's speech included a first ever mention of China's overseas responsibilities, and included a clear impetus for the Chinese Navy to ensure the security of the SLOCs, protect sea-related 
interests and participate in UN operations (McDevittand Jr., 2012: 83). In a speech to the China Community Party Congress in 2006, Jintao described China as a sea power and underlined PLAN's improved capabilities to protect maritime interests. Jintao is not the only one with such ideas. Around the same period, various Chinese government and navy officials issued statements, which correlated China's political and economic development with a need for a strong navy. Furthermore, several government agencies published studies regarding the matter (US DoD, 2009: 17-18). As a side note, it should be underlined that most of the aforementioned releases and statements consider China's dependency to SLOCs, particularly to the Indian Ocean and the Malacca Strait as a security issue.

China's shifting political and economic landscape expanded its navy's mission resulting in discussions regarding the extent to which the current strategy meets China's needs. In fact, indicators exist that China has been working on a new strategy, dubbed as the Far Sea Defense Strategy, since Jintao's 2004 speech. The main distinguishing characteristic of this policy from its predecessors is the implementation of certain tactics far away from the homeland, defending the SLOCs from greater distances and participating in non-combat operations in a consistent and effective manner (Murray et al. 2015: 110).

In a 2015 white paper published by the State Council of the People's Republic of China, it is stated that the navy is to focus on both defensive duties and the protection of overseas interests and defines a force structure suitable for the requirements of these new types of operations (The State Council, 2015). Some China experts indicate that the navy shall continue focusing on the Offshore Defense policy but will also seek to develop overseas operational capabilities, reserved for rare occasions. Advocates of the opposing view express that overseas operations shall be rendered routine in the near future and therefore conditions shall necessitate a transformation in terms of Distant Sea Defense (McDevittand Jr., 2012: 86). Recent developments tend to support the second view. However, regardless of what direction Chinese Naval Strategy evolves to, there is little doubt that PLAN will increase its presence in regions far from China's mainland. It is also clear that the modernization of its force structure has become a prerequisite. However, one equally critical aspect will be to have base and port facilities in the relevant regions, hence underscoring the importance of the $21^{\text {st }}$ Century Maritime Silk Road.

\section{THE CHINESE NAVY AND THE MARITIME SILK ROAD}

The Central Military Commission (CMC) sits firmly at the top of the Chinese military hierarchy. The CMC, headed by the Chinese President, is responsible for the determination and execution of general policies towards the PLA. There are four General Headquarters affiliated to the CMC: General Staff Department, General Political Department, General Logistics Department and General Armament Department. In this structure, PLAN operates under the General Staff Department (Office of Naval Intelligence, 2009: 12).

PLAN, headquartered in Beijing, consists of four first-level departments and three geographically-oriented fleets. The departments, which are responsible for providing all types of support to the fleets, are the Staff Department, Political Department, Logistics Department and Armament Department. The fleets that are tasked with naval operations are the Northern Sea Fleet, Eastern Sea Fleet and Southern Sea Fleet. The Qingdao-based Northern Sea Fleet is responsible for the Bohai Sea, the Yellow Sea and the East China Sea. The Ningbo-based Eastern Sea Fleet covers the majority of the Northern China Sea and the Taiwanese Strait, while the Zhanjiang-based Southern Sea Fleet is responsible for the South China Sea (Office of Naval Intelligence, 2009: 12-13). 
As of 2016, PLAN's inventory is comprised of 1 aircraft carrier, 4 SSBNs, 5 SSNs, 51 dieselelectric submarines (SSK), 19 destroyers, 54 frigates, 22 corvettes, 93 fast attack crafts (FAC), 84 patrol boats, 49 mine countermeasures vessels (MCMV), 3 landing platform docks (LPDs), 47 landing ships, 73 landing crafts and 171 auxiliary ships. In addition, the inventory includes various models of 514 fixed-wing and 111 rotating-wing aircrafts. Including conscripted military personnel, PLAN's total manpower is 235,000 people (IISS, 2016: 242 244).

In recent years, PLAN has been carrying out a comprehensive modernization program to improve its force. Amongst those procured systems that stand out are: aircraft carriers, submarines, destroyers, frigates, corvettes, patrol boats, landing ships, MCMVs, ASBMs, ASCMs, land attack cruise missiles (LACMs), surface-to-air missiles (SAMs), sea mines, unmanned aerial vehicles (UAVs) and C4ISR solutions. The modernization efforts also include streamlining logistics, strengthening sustainability and improving military doctrine, education/training and military exercises (O'Rourke, 2017: 2-3).

Today, the key platforms for becoming a global naval power are aircraft carriers and nuclear submarines. Therefore, although all military equipment carries some military importance, the two indicated warrant a more detailed discussion. PLAN commissioned its very first aircraft carrier named Liaoning (formerly known as Varyag) in 2012. Its sister, the first aircraft carrier to be completely built in China, is expected to begin sea trials in 2019. Currently, China is working on a third vessel that is aimed to be of an indigenous design. There are speculations that this vessel will deviate from its Russian-originated predecessors in terms of design, and rather will resemble its US counterparts. It may also be equipped with nuclearpowered propulsion systems and catapults. Experts underline that China needs to field two Aircraft Carrier Strike Groups in both the Western Pacific and the Indian Ocean in order to protect its sovereign claims and overseas interests. Furthermore, considering that some ships may be out of operational service during regular periods of maintenance and overhauls, it is estimated that at least 5-6 aircraft carriers will be needed in total (Seidel, 2017).

Although nuclear submarines in the Chinese Navy have a comparatively longer standing history, acceleration of new production has just begun. For many years, PLAN featured only one class of SSBN (Xia Class-Type 92). Furthermore, reports suggest that SSBN's, which debuted inthe 1980's and are out of commission today, never performed patrolling duties due to noise problems. The navy's current SSBN class is dubbed as the Jin Class (Type 94). The first submarine of this class was commissioned in 2014. China now has four of them. The US Department of Defense (DoD) estimates that this number will reach to eight by 2020. Each Jin Class submarine can carry twelve JL-2 Submarine-Launched Ballistic Missiles (SLBMs). After commissioning the aforementioned submarines, China initiated patrolling missions and thereby put the Sea-Based Nuclear Deterrence concept into practice for the first time in its history (Babiarz, 2017). It has also been reported that China is developing an improved version of its Type 94 submarines (Type 94A) (Lin and Singer, 2017). Others speculate that China is also developing a new generation of SSBN Class, called the Type 96, and is working on an extended range version of its JL-2 Missiles (JL-2A) (Babiarz, 2017). The SSN's on the other lie behind the other pillar of PLAN's nuclear submarine fleet. Currently, there are three Han (Type 91) Class and two Shang (Type 93) class SSN's available in force (IISS, 2016: 242). PLAN, however, seeks to decommission the Han Class nuclear submarines, which are far from meeting the requirements of modern submarine operations, and to begin working on a next generation of SSN's called Shang II (Type 93A) Class. In fact, some sources claim that the indicated SSN's have already been commissioned for development around the end of 
2016. Immaterial of its other ambitions, PLAN is expected to field two Shang and four Shang II class SSNs in its inventory (Boyd and Waldwyn, 2017).

Those observing the move towards the modernization of the Chinese Navy have hypothesized that these efforts aim to achieve the following: a) to bring a solution to the Taiwan issue, by force, if necessary, b) to support China's sovereignty claims in the South China and East China Sea, c) to regulate the military activities of foreign nations within the borders of China's EEZ (which stretches over some 200 miles), d) to protect the SLOCs, especially the one that connects the Persian Gulf to China, e) to reduce the US influence in the Western Pacific and, f) to contribute to China's vision to be a regional and global powerhouse. Given these goals, it is clear that PLAN seeks to become a force fully capable of implementing an A2/AD strategy, as previously discussed. We can then extrapolate that PLAN's primary task is to deter US intervention in the case of conflicts that may arise as a result of disputes in its surrounding seas. In the case of failure to accomplish this task, PLAN is to deny US forces access to its theater of conflict. PLAN's other tasks include exercising sea operations, which envisages activities such as combating against piracy, the evacuation of non-combatants and disaster relief support (O’Rourke, 2017: 5-6).

In recent years, the number of PLAN activities that seek to promote its presence and unfurl its flag has considerably increased. One pillar of those activities is comprised of worldwide port visits. This can be exemplified by the ten-month run of Task Force TF-152 that includes visits to ports in Europe, North America, the Pacific and Southeastern Asia. Temporary or permanent deployments in certain regions make up another pillar of this strategy. As evidenced in our discussion thus far, the Indian Ocean and the South China Sea are given an utmost and separate importance due to their geostrategic value related to energy supply and sovereignty claimsin those regions. In 2008, the Chinese Navy made its first debut in the Indian Ocean as a result of efforts to combat piracy in the Gulf of Aden (Suri, 2016: 22-23). PLAN operates in the area with naval task forces usually comprised of two frigates and one combat support ship. Its naval elements escort more than 6.400 commercial vessels with Chinese and foreign flags (Scimia, 2018). Another PLAN activity in the Indian Ocean is that of patrol missions, in operation since 2013, with at least seven (three are nuclear-powered) submarines (Singh, 2017b). PLAN has a permanent presence in the South China Sea. Even the fact that China's sole aircraft carrier, the Liaoning, has made its first long-term voyage to the area (VOA News, 2014) has sent a clear signal about China's ambitions to the international community.

In 2011 and 2015, PLAN was involved in operations for the evacuation of Chinese citizens and nationals of other countries in Libya and Yemen. The operation in Libya was recorded as a first for PLAN (Suri, 2016: 24). In recent years, PLAN's participation in multi-national military exercises has also increased. To be sure, many countries worldwide already undertake such operations and activities, however, the Russo-Chinese military exercises set themselves apart because of the consequences of that participation. In recent years, Russia and China completed a series of combined naval exercises in various regions including the Sea of Japan, Okhotsk Sea, the South China Sea, the Mediterranean and the Baltic Sea (Russia Matters, 2017). This raised some eyebrows, as some of these waters are under sovereign jurisdiction of other states, while others are the subject of strain between Russia and NATO.

In light of this analysis, it is clear that PLAN is advancing towards being a navy that is capable of executing global scale operations (in navy terms Blue Water Navy). The A2/AD strategy that China seeks to enforce in surrounding waters is, without a doubt. However, even 
this does not change that fact that the real heading of navy is the high seas. PLAN also continues to grapple with some major weaknesses among them are joint operations, antisubmarine warfare (ASW), foreign dependency in critical technologies and long-range striking capability (O'Rourke, 2017: 4).

Furthermore, the Chinese Navy also needs to improve on its maintenance and logistics capabilities. PLAN operations to be conducted in the areas that are far from the Chinese mainland will only continue to increase. Ensuring adequate logistical support for these kinds of operations may only be possible by obtaining a permanent base and port facilities in critical regions. China recognizes this need and has worked hard to increase its logistical capabilities in areas of interest, especially in the Indian Ocean. Initially, the work that China commissioned towards achieving these objectives was subsumed under the String of Pearls Strategy. The String of Pearls Strategy, first mentioned in a document prepared for the US DoD in 2004, is based on the premise that China's attempts to improve its diplomatic ties (and to obtain base and port facilities) with the countries that are situated within SLOCs from the Middle East to the south of China are conducted in line of a certain strategic scheme (Suri, 2016: 24). The Beijing Administration has neither denied nor accepted the existence of such a strategy. However, certain developments in the field have validated this premise. Undoubtedly, striking and noteworthy is the similarity between the $21^{\text {st }}$ Century Maritime Silk Road and the String of Pearls Strategy.

In summary, SLOCs and choke points, used by China today, are under the control of the US Navy. Whereas, the effectiveness of the Chinese Navy is particularly weak in the west of Malacca. Currently, the winner of a combat scenario in the Indian Ocean as well as the Persian Gulf and the Strait of Hormuz, is already clear. Right at this point, it is understood that China has taken a position against future crises. In this way, the role of the $21^{\text {st }}$ Century Maritime Silk Road Initiative, ensuring base and port facilities, is to expand the operational radius of the navy.

\section{CONCLUSION}

The One Belt, One Road Initiative has clearly demonstrated that one of China's main strategic imperatives is to consolidate its commercial and economic influence in its close neighborhood. A further step will be to integrate and propagate its political clout to transform China into a truly formidable global power. The $21^{\text {st }}$ Century Silk Road will act as an extension of the One Belt, One Road Initiative, and will be a conduit for China's commercial activities in Africa, the Middle East, and the states included in the "Bamboo Network". Though the initiative does set its sights on the Western Pacific and Mediterranean, Beijing's focus will certainly be on the South China Sea and the Indian Ocean corridor.

One of China's most important challenges is its dependency on Middle Eastern and African countries to meet its energy needs. The fact that energy imports must pass through SLOC's and choke points such as the straits of Hormuz and Malacca, most often under the control of the US and its allies, constitutes a serious security risk for Beijing.

In order to reduce these risks, China has leveraged the $21^{\text {st }}$ Century Maritime Silk Road Initiative to support commerce, finance, transportation and the transformation of its naval strategy. Hence, Beijing has formed close bonds with countries located on the South China Sea-Indian Ocean corridor and continues to work on a multiplicity of projects that aim to improve maritime transportation infrastructure. As an example, the Kra Channel anticipated to be built on Thai soil will become a serious alternative to the Malacca Strait. 
The $21^{\text {st }}$ Century Silk Road Initiative is helping to transform Chinese Naval Strategy and to help it transcend its current limitations to play in a larger arena. Extending the navy's operating radius will also help to cement Chinese ambitions for increased regional influence. A critical dimension necessary for the success of this strategic pursuit will be the establishment of overseas bases and port facilities in cooperating countries. This, then, highlights the importance of countries such as Sri Lanka, Djibouti and Myanmar for Beijing. It is clear that the Maritime Silk Road initiative has become part and parcel of a larger strategic endeavor to ramp up and transform the Chinese navy into a global power player. As China continues to harmonize its political, military, economic and commercial elements, it is clear that the country has embarked on a massive, long-term strategic endeavor to catapult it forward as a major global power into the next decade.

\section{REFERENCES}

AMIN, M. (2017). "How Sanctions-Stricken Sudan Sold Its Economy to China", Middleeast Eye, http://www.middleeasteye.net/news/made-china-how-sanctions-stricken-sudansold-itself-beijing-1669522131, (Accessed 01.04.2018).

BABIARZ, R. (2017). “China's Sea Based Nuclear Deterrent: Incremental Advances and Perennial Limitations”, Asia Dialogue, http://theasiadialogue.com/2017/04/05/ chinassea-based-nuclear-deterrent-incremental-advances-and-perennial-limitations/, (Accessed 01.02.2018).

BENDER, J. and Rosen, A. (2015). "This Pentagon Map Shows What's Really Driving China's Military and Diplomatic Strategy", Business Insider, https://www. businessinsider.in/This-Pentagon-map-shows-whats-really-driving-Chinas-militaryand-diplomatic-strategy/articleshow/47273547.cms, (Accessed 01.02.2018).

BENNETT, D. (2010). "An Analysis of the China's Offshore Active Defense and the People's Liberation Army Navy”. Global Security Studies, 1(1), 126-141.

BLANCHARD, J.-M. F. and FLINT, C. (2017). "The Geopolitics of China's Maritime Silk Road Initiative". Geopolitics, 22(2), 223-245.

BOYD, H. and WALDWYN, T. (2017). “China's Submarine Force: An Overview”, IISS, https://www.iiss.org/en/militarybalanceblog/blogsections/2017-edcc/october-

0c50/chinas-submarine-force-1c50, (Accessed 01.02.2018).

CAI, P. (2017). “Understanding China's Belt and Road Initiative”. Lowy Institute Policy Analysis.

CHATURVEDY, R. R. (2017). "China's Strategic Access to Gwadar Port: Pivotal Position in Beltand Road”. RSIS Commentary, No. 5.

China Daily (2014). "Malaysia Becomes China's 3rd Largest Trade Partner in Asia", http://www.chinadaily.com.cn/business/2014-01/21/content_17247588.htm, (Accessed 29.03.2018).

CONNELLY, A. L. (2017). “Indonesia's New North Natuna Sea: What's in a Name?”, Lowy Institute The Interpreter, https://www.lowyinstitute.org/the-interpreter/indonesia-snew-north-natuna-sea-what-s-name, (Accessed 29.03.2018).

ENGELBREKT, K. and Watts, J. (2015). "Sino-Russian Strategic Cooperation: Still An "Axis of Convenience". Swedish Defence Univesity Report. 
GADKARI, N. (2018). "India-Thailand-Myanmar Trilateral Highwayby 2019”, Live Mint, https://www.livemint.com/Politics/hdV9E00I5CwSrKmSheAu6M/IndiaMyanmarThai land-Trilateral-Highway-by-2019-Nitin-Gad.html, (Accessed 31.03.2018).

Global Security (w.date). "People's Liberation Navy - Offshore Defense", https://www.globalsecurity.org/military/world/china/plan-doctrine-offshore.htm, (Accessed 18.01.2018).

GREITENS, S. C. (2016). "The US-Philippine Alliance in a Year of Transition: Challenges and Opportunities”. Brookings Asian Alliances Working Paper Series, No. 5.

HAN, D. (2016). "Malaysia's South China Sea Policy: Contradictions or Domestic Confusion". RSIS Commentary, No. 88.

HARTNETT, D. (2014). "The Father of the Modern Chinese Navy: Liu Huaqing”,CIMSEC, http://cimsec.org/father-modern-chinese-navy-liu-huaqing/13291, 19.01.2018).

HEYDARIAN, R. J. (2017). "Tragedy of Small Power Politics: Duterte and the Shifting Sands of Philippine Foreign Policy". Asian Security, 13 (3), 220-236.

HUANG, Z. (2017). "Your Guide to Understanding OBOR, China's New Silk Road Plan", Quartz, https://qz.com/983460/obor-an-extremely-simple-guide-to-understandingchinas-one-belt-one-road-forum-for-its-new-silk-road (Accessed 28.03.2018).

HUSSAIN, Z. (2017). "The China-Pakistan Economic Corridor and the New Regional Geopolitics". IFRI-Center For Asian Studies, Asie-Visions, No. 94.

IISS (2016). The Military Balance 2016: The Annual Assessment of Global Military Capabilities and Defence Economics, London: The International Institutefor Strategic Studies.

KHAN, S. A. (2013). "Geo-Economic Imperatives of Gwadar Sea Port and Kashgar Economic Zone for Pakistan and China”. IPRI Journal, 13(2), 87-100.

KOLAS, A. (2007). "Burma in the Balance: The Geopolitics of Gas". Strategic Analysis, 31(4), 625-643.

KRATZ, A. and Pavlicevic, D. (2016). "China's High-Speed Rail Diplomacy: Riding A Gravy Train?”. Lau China Institute Working Paper Series.

KUO, L. (2017). “There's At Least One Place in Africa Where China's Win-Win Diplomacy is Failing", Quartz, https://qz.com/1111402/south-sudan-china-win-win-diplomacystruggles, (Accessed 01.04.2018).

LIN, J. and Singer, P. W. (2017). "China’s New Ballistic Missile Submarine Could Change Its Prospects in Nuclear War", Popular Science, https://www.popsci.com/chinaballistic-missile-submarine-type-094a-ssbn, (Accessed 01.02.2018).

LINTNER, B. (2017). "Myanmar As China's Corridor to the Sea", Asia Times, http://www.atimes.com/article/myanmar-chinas-corridor-sea, (Accessed 31.03.2018).

MCDEVITT, M. and Jr., F. V. (2012). "The Evolution of the People's Liberation Army Navy: The Twin Missions of Area-Denial and Peacetime Operations". Geoffrey Till ve Patrick C. Bratton (ed.), Sea Power and the Asia-Pacific: The Triumph of Neptune?, Abingdon ve New York: Routledge, 75-92. 
MURDOCH, L. (2017). "Thailand's Kra Canal Plan Would Link Indian, Pacific Oceans Benefiting China". The Sydney Morning Herald, https://www.smh.com.au/world/thailands-kra-canal-plan-would-link-indian-pacificoceans-benefiting-china-20170808-gxrgz1.html, (Accessed 28.03.2018).

MURRAY, C. et al. (2015). “China's Naval Modernization and Implications for the United States". Douglas C. Lovelace Jr. (ed.), Terrorism Commentery on Security Documents: The Rise of China, New York: Oxford University Press, 109-120.

OEC (2016a). "Indonesia”, https://atlas.media.mit.edu/en/profile/country/idn, (Accessed 29.03.2018).

OEC (2016b). "Philippines", https://atlas.media.mit.edu/en/profile/country/phl, (Accessed 30.03.2018).

Office of Naval Intelligence (2009). The People's Liberation Army Navy: A Modern Navy With Chinese Characteristics, Fort Belvoir: Defense Technical Information Center.

Office of Naval Intelligence (2015). The PLA Navy: New Capabilities and Missions for the 21st Century. Fort Belvoir: Defense Technical Information Center.

O'ROURKE, R. (2017). China Naval Modernization: Implicationsfor U.S. Navy Capabilities - Background and Issues for Congress. Washington: Congressional Research Service.

PALIT, A. (2016). "India's Act East Policy and Implications for Southeast Asia”. Southeast Asian Affairs, No. 1, p. 81-91.

PANDA, J. (2016). India-China Relations: Politics of Resources, Identity and Authority in a Multipolar World Order. London: Routledge Publishing.

PARAMESWARAN, P. (2018). "What's Next For China-Thailand Military Ties in 2018?”, The Diplomat, https://thediplomat.com/2018/02/whats-next-for-china-thailandmilitary-ties-in-2018, (Accessed 28.03.2018).

PERLEZ, J. (2012). "Vietnam Law on Contested Islands Draws China's Ire", The New York Times, https://www.nytimes.com/2012/06/22/world/asia/china-criticizes-vietnam-indispute-over-islands.html, (Accessed 30.03.2018).

PERLEZ, J. (2017). "China Showers Myanmar with Attention As Trump Looks Else Where”, The New York Times, https:/www.nytimes.com/2017/07/19/world/asia/myanmarchina-us-diplomacy-trump.html, (Accessed 31.03.2018).

PING, C. K. (2017). "Singapore, China Ink Pacts on Suzhou Industrial Park, Tianjin Eco-City and Other Bilateral Projects”. The Straits Times, February 27, 2017.

PwC (2015). “The World 2050: Will the Shift in Global Economic Power Continue?", https://www.pwc.com/gx/en/issues/the-economy/assets/world-in-2050-february2015.pdf, (Accessed 02.02.2018).

QUINLAN, J. (2007). “Insight: China's Capital Targets Asia's Bamboo Network”, Financial Times, https://www.ft.com/content/67554d8a-920f-11dc-8981-0000779fd2ac, (Accessed 29.03.2018).

RAMAN, S. (2016). “The Strategic Importance of Andaman and Nicobar Islands", The Diplomat, https://thediplomat.com/2016/01/the-strategic-importance-of-andaman-andnicobar-islands, (Accessed 31.03.2018). 
Reuters (2017). "China Formally Opens First Overseas Military Base in Djibouti", https://www.reuters.com/article/us-china-djibouti/china-formally-opens-first-overseasmilitary-base-in-djibouti-idUSKBN1AH3E3, (Accessed 31.03.2018).

Reuters (2018). "Vietnam Halts South China Sea Oil Drilling Project Under Pressure From Beijing”, https://www.reuters.com/article/us-southchinasea-vietnam/vietnam-haltssouth-china-sea-oil-drilling-project-under-pressure-from-beijing-idUSKBN1GZ0JN, (Accessed 30.03.2018).

ROY, S. (2017). "How Chabahar Port Could Bring India and Its Partners a New Spring?", The Indian Express, http://indianexpress.com/article/explained/how-chabahar-portcould-bring-india-and-its-partners-iran-afghanistan-and-a-new-spring-4966443, (Accessed 31.03.2018).

RussiaMatters (2017). "Growing Scope of Russian-Chinese Naval Exercises Points to Closer Ties", https://www.russiamatters.org/blog/growing-scope-russian-chinese-navalexercises-points-closer-ties, (Accessed 02.02.2018).

SCHULTZ, K. (2017). "Sri Lanka, Struggling with Debt, Hands a Major Port to China", The New York Times, https://www.nytimes.com/2017/12/12/world/asia/sri-lanka-chinaport.html, (Accessed 31.03.2018).

SCIMIA, E. (2018). “Anti-Piracy Mission Helps China Develop Its Blue-Water Navy”, Asia Times, http://www.atimes.com/anti-piracy-mission-helps-china-develop-blue-waternavy/ (Accessed 01.02.2018).

SEIDEL, J. (2017). "China is About to Launch Its Second Aircraft Carrier, 001A", http://www.news.com.au/technology/innovation/china-is-about-to-launch-its-secondaircraft-carrier-001a/news-story/ce97a88eba53b00ea37892698b12504c (Accessed 31.01.2018).

SIDDIQUI, S. (2017). "CPEC Investment Pushed From \$55b to \$62b”, The Express Tribune, https://tribune.com.pk/story/1381733/cpec-investment-pushed-55b-62b, (Accessed 28.03.2018).

SINGH, A. (2017a). "Countering China's Submarine Presence in the Indian Ocean", The Maritime Executive, https://www.maritime-executive.com/editorials/counteringchinas-submarine-presence-in-the-indian-ocean\#gs.gZXxHuo, (Accessed 31.03.2018).

SINGH, A. (2017b). "CounteringChina'sSubmarine Operations in South Asia", Lowy Institute, https://www.lowyinstitute.org/the-interpreter/countering-china-s-submarineoperations-south-asia, (Accessed 01.02.2018).

Sputniknews (2017). "Sheikhs For Djibouti: Nation's Defense Minister Welcomes Saudi Military Base", https://sputniknews.com/middleeast/201711281059503385-djiboutisaudi-military-base, (Accessed 31.03.2018).

STOREY, I. (2006). “China's Malacca Dilemma”. China Brief, Vol. 6, No. 8, https://jamestown.org/program/chinas-malacca-dilemma/, (Accessed 02.02.2018).

SUN, D. and Zoubir, Y. H. (2016). "The Eagle's Nest in the Horn of Africa: US Military Strategic Deployment in Djibouti”. Africa Spectrum, 51(1), 111-124.

SURI, G. (2016). China's 21st Century Maritime Silk Road: Old String with New Pearls?. New Delhi: Vivekananda International Foundation. 
TAI, M. (2017). “Gwadar: A Case of South-South Cooperation”. Cambridge Journal of Eurasian Studies, No. 1, 1-12.

TARABAY, J. (2017). "Singapore's Delicate Balancing Act Between the US and China", https://edition.cnn.com/2017/10/24/politics/singapore-lee-hsien-loong-trumpchina/index.html, (Accessed 29.03.2018).

TATA, S. (2017). "Deconstructing China's Energy Security Strategy", The Diplomat, https://thediplomat.com/2017/01/deconstructing-chinas-energy-security-strategy/ (Accessed 01.02.2018).

The State Council (2015). "China's Military Strategy", http://english.gov.cn/archive/ white_paper/2015/05/27/content_281475115610833.htm, (Accessed 18.02.2018).

TNI (2016). "China's Engagement in Myanmar: From Malacca Dilemma to Transition Dilemma”. Myanmar Policy Briefing, No. 19.

Tuan, H. A. and Thuy, D. T. (2016). "US-Vietnam Security Cooperation: Catalyss And Constraints". Asian Politics \& Policy, 8(1), 179-192.

US DoD (2009). “Military Power of the People's Republic of China 2009”. Annual Report to Congress.

VOA News (2014). “China's Aircraft Carrier Returns From South China Sea Mission”, https://www.voanews.com/a/chinas-aircraft-carrier-returns-from-south-china-seamission/1821831.html, (Accessed 02.02.2018).

WESANGULA, D. (2018). "Kenya Gambles on Dirty Energy with Its First Coal Plant", Huffington Post, https://www.huffingtonpost.com/entry/lamu-kenya-coalplant_us_5aa7a8d5e4b009b705d5f3ac, (Accessed 01.04.2018).

Xinhua (2017). "Backgrounder: Kenya's New Standard Gauge Railway", http://www.xinhuanet.com/english/2017-05/31/c_136326472.htm, (Accessed 01.04.2018).

ZHANG, F. (2017). "Chinese Thinking on the South China Sea and the Future of Regional Security”. Political Science Quarterly, Vol. 132, No. 3, p. 435-466.

ZHANG, X. (2015). Deng Xiaoping's Long War: The Military Conflict Between China and Vietnam, 1979-1991. North Carolina: University of North Carolina Press.

ZHEN, L. (2017). "Singapore-Taiwan Military Agreement to Stay in Place Despite Pressure From Beijing", South China Morning Post, http://www.scmp.com/news/ china/diplomacy-defence/article/2114170/no-reason-singapore-cut-military-tiestaiwan-sources, (Accessed 29.03.2018). 